\title{
Increasing Teacher Skills in Supporting Students With Special Needs
}

\author{
Nur Eva ${ }^{1^{*}}$, Muhammad Iqbal Fakhrul Firdaus ${ }^{1}$, Aditya Ananta Parameswara ${ }^{1}$, \\ Afnan Hari Pratama ${ }^{1}$, Sri Andayani ${ }^{2}$, Bakhitah Jihan Wijaya ${ }^{1}$, Syafira Triesna \\ Adinda ${ }^{1}$, Dwi Aji Setyo Pranoto", Hasan Said Tortop ${ }^{3}$ \\ ${ }^{1}$ Faculty of Educational Psychology, Universitas Negeri Malang, Malang, Indonesia \\ ${ }^{2}$ Faculty of Psychology, Airlangga University, Surabaya, Indonesia \\ ${ }^{3}$ Istambul Universitas Istanbul Esenyurt, Turki \\ ORCID \\ Nur Eva; https://orcid.org/0000-0003-3584-5049
}

Corresponding Author: Nur Eva; email: nur.eva.fppsi@um.ac.id

\section{Dates}

Published 28 January 2022

Publishing services provided by Knowledge E

(C) Nur Eva et al. This article is distributed under the terms of the Creative Commons

Attribution License, which permits unrestricted use and redistribution provided that the original author and source are credited.

Selection and Peer-review under the responsibility of the ICoPsy Conference Committee.
Abstract. The education sector in Indonesia is still colored by various problems. These are caused by several factors, such as the lack of effectiveness of education, the lack of efficiency of learning implementation, and the lack of standardization of learning for students with special needs. This study aimed to develop effective competencies in the identification of and intervention with students with special needs in schools. This study used a quantitative approach with a one-group pre-test post-test experimental design. Material presented in the training sessions included the basic concepts of inclusive education, the characteristics of students with special needs, how to teach students with special needs, and how to make individual learning programs. The instruments used in this study for the purposes of the pre-test and post-test were developed by the researchers based on theories and models. A total of 10 items were used in the instrument. Data were analyzed using the Cohen's D t-test method, which produced a $\mathrm{p}$-value of 0.843; as this is $>0.05$, this indicated that there was no difference between before and after the training. Based on the research and workshops conducted by the researchers, it was found that most teachers lacked the motivation to apply training materials for working with students with special needs, even though the level of teachers' participation in the trainings was high. The results showed that the trainings were not able to significantly influence the skills of teachers in teaching students with special needs. Therefore, other methods are needed to improve the knowledge and abilities of teachers in supporting students with special needs.

Keywords: teaching skills, training, students with special needs

\section{Introduction}

There are still many problems in educational sector in Indonesia today. These problems are caused by various factors, such as low level of effectiveness of education, lack of efficiency in the implementation of learning, and lack of standardization of learning, especially for students with special needs. In education for students with special needs, other problems that often arise apart from the students themselves are the inability of schools to meet the facilities and infrastructure that support their development, the 
lack of teacher competence in identifying and handling students with special needs, inequality in access to education for students with special needs, and the high cost of education and psychological intervention for children.

These problems are the focus of the government and educational institutions in order to realize a higher quality of national life, especially for children with special needs. The number of children with special needs is increasing day by day. In 2017 alone, the Central Bureau of Statistics (BPS) noted that there were 1.6 million children with special needs spread throughout Indonesia, both those who had received inclusive education, general education, or who had not yet received access to education at all due to age, economy, and parental awareness.

All Indonesian citizens, both those with normal development or those with special needs, have equal access to education, as an effort to create Indonesian people who have superior abilities and personalities. One of the groups that need special attention in terms of education is the group of children with special needs. Psychologically, students with special needs are students with physical and cognitive problems that can interfere with the continuity of their learning. However, it is possible that they will be able to progress in cognitive, socio-emotional, and psychomotor development if they receive proper treatment.

The problem is, often the identification and handling of students with special needs produce vague and even wrong conclusions, so that the learning provided is less adaptive to the limitations experienced by students, so that students feel left behind and less than optimal in carrying out learning activities. This can certainly have a negative impact on students, teachers, parents, educational institutions, and even for the Indonesian nation as a whole. Therefore, it takes people who have qualified competence in identifying and handling students with special needs

\section{Literature Review}

\subsection{Adult Teaching (Andragogy)}

Adult teaching or andragogy is the entire educational process whose content, levels, and methods are formally organized in schools, colleges, universities, and vocational training centers with the aim of making people who are considered adults by society develop abilities, enrich knowledge, improve technical qualifications or professional development, as well as change their attitudes and behavior in accordance with full 
personal development and participation in free and proportional social, economic and cultural development [1].

Andragogy can also be defined as providing assistance to adult individuals so that they can learn optimally. Thus, it can be said that andragogy is education given with the aim of teaching adult individuals [2]. Indeed, education continues to be needed by humans throughout life, not only in childhood, because humans continue to experience development from children to adults. Therefore, human learning at each stage of development is also different. In this case, adult individuals need the provision of educational services that specifically teach them.

Andragogy is education given to adult individuals by using some of their time without coercion and purely to increase their knowledge, skills, and positive attitudes to develop themselves as individuals who actively participate in social, economic, and cultural development in a balanced and comprehensive manner [3]. Adult education or andragogy is all educational activities carried out by adult individuals in everyday life by using some of their time and energy to improve their intellectual abilities [4].

According to [5], there are several principles of andragogy, namely as follows:

a. The desire to learn, is a very important principle in increasing the effectiveness of learning. The desire to learn can arise because of a deep interest in an object or a need for a particular knowledge or skill. In addition, the desire to learn can grow from encouragement or motivation from others.

b. Understanding of the task. Learners get a clear understanding of the tasks that must be done to achieve the goals that have been set. They also need to know what to read, record, study, practice, discuss, research, practice, and do.

c. Association law. Learning by connecting various ideas and facts tends to be able to produce a more permanent memory than learning without connecting various ideas and facts. This method is one of the characteristics of learning from adult individuals that distinguishes it from the learning of children. Adult individuals are able to relate various concepts and analyze them to produce a conclusion. They can apply the principles being studied to various situations in life. Association law has an important characteristic, namely that new ideas or experiences can be meaningful if they are associated with real ideas or experiences that have occurred before.

d. Interest, tenacity, and intensity. Learning is less effective if an exercise or repetition activity is not based on interest. Research proves that interest or will, tenacity or persistence, and intensity greatly affect learning success. The tenacity and 
intensity of the learning experience can have a significant effect on individual memory. If these two things are supported by a high interest in learning, students will have engagement with the given task, have great attention to their works, and enjoy their works.

e. Firmness of stance. Firmness of stance will determine whether the individual continues his activities or not. If the individual's stance is filled with prejudice, suspicion, and closedness, the effectiveness of learning will be hampered. A learner should have determination and willingness to accept new ideas even if they have no desire to implement them.

f. Knowledge of success and failure. A learner of andragogy or adult individual learning cannot make progress in the learning process when he is not able to know whether the efforts made are successful or unsuccessful. A highly desirable situation in individual adult education or andragogy is a situation where the learner has the ability to evaluate his or her own work using criteria or standards designed specifically for that learning.

Based on this explanation, it can be concluded that andragogy is education aimed at adults by using part of their time voluntarily. In addition, andragogy is expected to produce outcomes in the form of increased knowledge, skills, changes in attitudes, self-development as individuals, and participation in social, economic, and cultural development. Adult education is not always done formally, although most of it is done through educational institutions with structured learning. Basically, adult education or andragogy can also involve daily activities carried out by adult individuals to improve their intellectual abilities.

\subsection{Trainings}

If individuals are going to do a job that they think is a foreign job, they need to learn how to do the job. Almost no individual is able to do a job well if they don't learn it first, even though the job looks easy. In various institutions, both government agencies and private institutions, the placement of individuals in a particular job or position is expected to make them successful in doing any given job. Thus, training is needed to improve individual performance in doing their current and future works [6].

Furthermore, stated that training aims to improve the mastery of certain skills and jobs on a regular and detailed basis[7]. According to training is all planned efforts made by individuals to achieve mastery of a certain skill, knowledge, or attitude that is relevant to 
the job [8]. Based on the description above, it can be seen that training is very important because training involves systematic processes and activities carried out by individuals to improve and develop their knowledge, skills, attitudes, and behavior so that they can achieve organizational goals.

Training can be carried out to ensure the availability of human resources in the organization who have the expertise and ability to think critically. In addition, training can also contribute to increasing organizational stability and encourage individuals to continue to increase dedication and loyalty in the long term. As human resources in the field of education, teachers need to receive training systematically in order to be able to carry out their work well. In addition to thoroughness in the selection process and the talent shown during work, teachers also need systematic training to achieve the best performance while carrying out their work.

In general, stated that some of the goals that can be achieved when conducting training are increasing individual satisfaction, increasing financing efficiency, reducing absenteeism and turnover, improving work methods and systems, increasing income, reducing overtime costs and infrastructure maintenance, reducing complaints from parties [9]. external factors, reducing work accidents, improving collective organization, increasing individual multipurpose knowledge, improving individual morality, and realizing better cooperation.

All of these goals certainly cannot be achieved with one type of training, because the objectives of various trainings certainly have differences from one another. Before carrying out a training, the thing that needs to be considered is the goal to be achieved through the training. Meanwhile, the training has four general objectives, namely to improve, speed up, and increase work efficiency; control work accidents; increase responsibility and discipline; and strengthen professionalism in office [10]. That is, if individuals have received special training related to the work they are doing, they are less likely to make mistakes. If employees carry out work with fewer errors, the leader does not take long to supervise.

The training program has various benefits for both schools and teachers. For schools, training can increase school work productivity, create a harmonious relationship between superiors and subordinates, speed up the decision-making process, increase work motivation and organizational commitment, encourage management openness through the application of a participatory managerial style, facilitate and improve communication effectiveness, and resolve conflicts. functionally. As for teachers, training can help them to make better decisions, improve their ability to solve various problems, improve the internalization and operationalization of motivational factors, encourage 


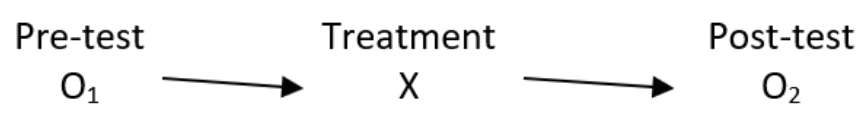

Description:

$\mathrm{O}_{1}$ : Pre-test

$\mathrm{X}$ : Treatment (Training Activities)

$\mathrm{O}_{2}$ : Post-test

SCHEME 1: Research Design.

increased work skills and deal with work stress, increase job satisfaction, increase teacher motivation to be more independent, and reduce fear in facing various tasks in the future [11].

Based on this explanation, it can be said that training is an activity that involves twoway communication between the training provider and the individual being trained. Every educational institution needs to understand various things, namely the needs of teachers, the progress of services to teachers and students, providing intensive guidance to teachers without always using direct materials, sources of teacher satisfaction related to existence in schools, the importance of creating a pleasant work and school atmosphere, and setting an example in goodness, quality, and discipline. Good training is a training that has objectives in accordance with educational needs, has training materials that are relevant to the realization of training objectives, has a schedule that is conducive to both the giver and trainees, is held in a location that attracts the enthusiasm of the trainees, filled by presenters according to the required qualifications, and delivered in a method that is in accordance with the training participants and the material provided.

\section{Method}

This study used an experimental research design of one group pre-posttest design, which is illustrated in the schema below.

Before the training begun, participants were given a pre-test in the form of knowledge questions that aimed to measure the participants' knowledge before the training was carried out. The instruments used in this study for the purposes of pretest and posttest were developed by researchers based on theories and modules. A total of 10 items were used in the instrument. The treatment given was in the form of training in the development of learning methods for students with special needs. The training was given for two consecutive days. The time of training activities per day is about 3 hours, 
TABLE 1: Training Activities on the Learning Method for Students with Special Needs

\begin{tabular}{|c|c|}
\hline Session & Activity \\
\hline \multicolumn{2}{|r|}{ Day 1} \\
\hline 1 & $\begin{array}{l}\text { Introduction and delivery of obstacles in conducting learning for } \\
\text { students with special needs }\end{array}$ \\
\hline 2 & Material 1 Knowing about Inclusive Education \\
\hline 3 & $\begin{array}{l}\text { Watching Videos about Characteristics of Students with Special } \\
\text { Needs }\end{array}$ \\
\hline 4 & $\begin{array}{l}\text { Material } 2 \text { Knowing the Characteristics of Children with Special } \\
\text { Needs and Practical Advice for Teaching Children with Special } \\
\text { Needs }\end{array}$ \\
\hline 5 & Review 1 \\
\hline \multicolumn{2}{|r|}{ Day 2} \\
\hline 6 & Material 3 Individual Learning Program \\
\hline 7 & Individual Learning Program Creation \\
\hline 8 & Presentation and Discussion \\
\hline 9 & Review 2 \\
\hline
\end{tabular}

TABLE 2: Descriptive Statistics

\begin{tabular}{l|l|l|l|l|} 
& $\mathrm{N}$ & Mean & SD & SE \\
\hline Pre Test & 10 & 6.2 & 2.821 & 0.892 \\
\hline Post Test 10 & 5.9 & 3.381 & 1.069 \\
\hline
\end{tabular}

starting from 9-12 hours. Then after the training was completed, participants were also given the same questions. The training was conducted for two days, by conducting several sessions as follows:

Data analysis used in this research is the Cohen's D t-test method. If the Cohen's D score shows a result above 1, then the hypothesis is accepted, which means that the treatment effect is significant on improving teacher skills in teaching students with special needs.

\section{Result}

The data analyzed showed that the mean value of the post test was higher than that of the pretest. The difference between the two was 0.3. This means that there is a decrease in participants' knowledge about the learning development of students with special needs, after the training.

Before testing the hypothesis, the data normality test was carried out using the Shapiro-Wilk method. This method was used because the amount of data analyzed 
TABLE 3: Normality Test

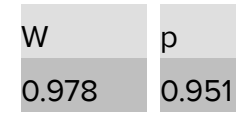

TABLE 4: Hypothesis Testing

\begin{tabular}{|l|l|l|l|l|l|}
\hline$t$ & $d f$ & $p$ & Mean difference & SE Difference & $\begin{array}{l}\text { Cohen's } \\
\text { D }\end{array}$ \\
\hline 0.204 & 9 & 0.843 & 0.3 & 1.469 & 0.065
\end{tabular}

was less than 30 . The results of the data normality test showed that the data were normally distributed with $\mathrm{p}$ value $=0.951>0.05$.

Hypothesis testing in this study resulted in a $\mathrm{p}$ value $=0.843>0.05$, meaning that there was no difference between before and after the training. The magnitude of the effect of treatment in the form of training on the posttest results was indicated by the Cohen's $D$ value below 1 which was 0.065 , which means that the treatment effect is of small value.

\section{Discussion}

The results of hypothesis testing indicated that the changes that occurred were not significant so that it can be said that the treatment in the form of training does not bring the changes that occur. If it was further analyzed, it appears that the pre-test scores of the trainees were on average 6.2. Roughly this value can be interpreted that more than 50 percent of the questions can be answered correctly. The decline in post-test scores requires further analysis, the researcher found that some participants were absent on the second day so their post-test scores were considered 0 (zero). Evaluation on pretest and post-test only referred to mere understanding. The evaluation of skills was recorded qualitatively in the form of narrative observations so that it requires conversion of assessment from qualitative to quantitative.

Based on hypothesis testing, there is no significant difference in the teaching skills of students with special needs before and after the training. This is indicated by the Cohen's D coefficient of 0.065 which made the training contribution only 6.5 percent. Training actually did affect the competence of teachers, both pedagogic, personality, social, and professional competencies in providing learning to students with special needs. All teachers did attend the training, but most of the teachers who participated in the training lacked the knowledge and motivation to apply the training materials to the fullest. It can be seen from the total pre-test and post-test scores of the trainees 
that did not change significantly, even the average post-test score was lower than the pre-test. In general, a training is designed with relevant quality, quantity, time, and cost, but there are times when some trainings are not able to achieve all of them, according to the opinion expressed [12] who stated that training is only beneficial for teachers if they have a strong determination to develop their skills and level of ability. Individual performance can indeed increase along with the increase in the intensity of the training carried out. However, the findings of this study indicated that there is no significant difference between the teaching abilities of teachers before and after attending the trainings.

\section{Conclusion}

Based on the results of this study, it can be seen that trainings have not been able to contribute significantly to the ability and skills of teachers in conducting learning to students with special needs, as indicated by Cohen's D coefficient which did not reach 0.5. Thus, other methods are needed to improve the abilities and skills of teachers in conducting learning to students with special needs.

\section{Acknowledgment, Funding, \& Ethics Policies}

This research was funded by the Non-Tax State Revenue Grant (PNBP) for the Psychological Education Faculty, State University of Malang of 2021.

\section{References}

[1] Merriam SB, Bierema LL. Adult learning: Linking theory and practice. New Jersey: John Wiley \& Sons; 2013.

[2] Krajnc A. The study of andragogy and education of andragogues. The Andragogic Perspectives. 2011;2(0):28-43. Available From: $\quad$ https://web.p.ebscohost.com/abstract?direct=true\&profile= ehost \&scope $=$ site $\&$ authtype $=$ crawler $\&$ jrnl $=13185160 \& A N=63281920 \& \mathrm{~h}=$ LnHEljZJPF8aJDqcIOJiXMmNydM70dfL3LadaQYbvaV1F9Ne357QWMoVYi1ECiiZIbl\% $2 \mathrm{feVfm} 1 \mathrm{GwdV3CkZ5FfoQ \% 3d \% 3d \& crl=c \& resultNs=AdminWebAuth \& resultLocal=}$ ErrCrINotAuth\&crlhashurl=login.aspx\%3fdirect\%3dtrue\%26profile\%3dehost\% 26scope\%3dsite\%26authtype\%3dcrawler\%26jrnl\%3d13185160\%26AN\%3d63281920 
[3] Livingstone DW, Sawchuk P. Hidden knowledge. Toronto: University of Toronto Press; 2019.

[4] Brockett RG, Hiemstra R. Self-direction in adult learning: Perspectives on theory, research, and practice. New York: Routledge; 2018.

[5] Ekoto CE, Galkwad P. The impact of andragogy on learning satisfaction of graduate students. American Journal of Educational Research. 2015;3(11):1378-1386. https://doi.org/10.12691/education-3-11-6

[6] Rahayu M, Rasid F, Tannady H. The effect of career training and development on job satisfaction and its implications for the organizational commitment of regional secretariat (SETDA) employees of Jambi provincial government. International Review of Management and Marketing. 2019;9(1):79. https://doi.org/10.32479/irmm.7439

[7] Slavich GM, Zimbardo PG. Transformational teaching: Theoretical underpinnings, basic principles, and core methods. Educational Psychology Review. 2012;24(4):569-608. https://doi.org/10.1007/s10648-012-9199-6

[8] Mathieu JE, Martineau JW. Individual and situational in?uences on training motivation. Ford JK, editor.Improving training e?ectiveness in work organizations. New Jersey: Lawrence Erlbaum Associates Publisher; 1997.

[9] Adhikari DR, Hirasawa K, Takakubo Y, Pandey DL. Decent work and work life quality in Nepal: An observation. Employee Relations. 2012;34(1):61-79. http://dx.doi.org/10.1108/01425451211183264

[10] Kondalkar VG. Organizational behaviour. New Delhi: New Age; 2020.

[11] Cheon S-H, Reeve JM. Do the benefits from autonomy-supportive PE teacher training programs endure?: A one-year follow-up investigation. Psychology of Sport and Exercise. 2013;14(4):508-518. http://dx.doi.org/10.1016/j.psychsport.2013.02.002

[12] Ten Cate OTJ, Kusurkar RA, Williams GC. How self-determination theory can assist our understanding of the teaching and learning processes in medical education. Medical Teacher. 2011;33(12):961-973. https://doi.org/10.3109/0142159x.2011.595435 